Мединець О. Е., аспірант *

Полтавська державна аграрна академія

\title{
ВПЛИВ ЧАСУ ВІДНОВЛЕННЯ ВЕСНЯНОЇ ВЕГЕТАЦІЇ ПШЕНИЦІ ОЗИМОЇ НА РОЗВИТОК БУРОЇ ЛИСТКОВОЇ ІРЖІ
}

\section{Рецензент - кандидат сільськогосподарських наук Г. Д. Поспєлова}

\begin{abstract}
На підставі аналізу архівних матеріалів 55-річних спостережень Миргородської сортодільниці Полтавської області встановлено залежність ураження пшениці озимої бурою листковою іржею від часу відновлення весняної вететациї (ЧВВВ) рослин та періодичності сонячної активності. ЧВВВ є комплексним показником наступних світлових, теплових $i$, частково, водних умов весняного розвитку рослин, щцо зимують. Максимальне ураження посівів бурою іржею (57-81\%) спостерігалося в роки з середньою сонячною активністю (61-120 W) за оптимального $i$ пізнього ЧВВВ. Мінімальне ураження, яке не потребує застосування заходів захисту, спостерігалося за двох поєднань ичих показників: 1) у роки з раннім ЧВВВ (до 20 березня) незалежно від сонячної активності і 2) в роки високої сонячної активності (121190 W) за слабкої залежності від ЧВВВ. Таких років було 28 із 55-ти. Отримані результати можуть бути використані в прогнозуванні розвитку бурої іржі пиениці озимої.
\end{abstract}

Ключові слова: пшениця озима, час відновлення весняної вегетаиії, бура листкова іржа пшеничі, прогнозування, періодичність сонячної активності.

Постановка проблеми. Бура листкова іржа пшениці (збудник Puccinia recondita f. sp. tritici Rob. ex Desm) є однією 3 найпоширеніших хвороб [1]. Втрати урожаю пшениці озимої від ї ураження становлять від 3-х до 10-15-и ц/га i більше [9]. В боротьбі з хворобою важливо мати завчасний оперативний прогноз розвитку патогена, щоб не допустити несподіваних епіфітотій або зайвого пестицидного навантаження на довкілля. Існуючі нині способи прогнозування перебігу хвороби грунтуються на передбаченні фази в багаторічному циклі патогена та малонадійних прогнозах погоди, тобто, в свою чергу, прогнозованих параметрах, а не на дійсних фактах. Для поліпшення названого прогнозу необхідно виявляти додаткові чинники, що впливають на ураження рослин цією хворобою. Одним із таких чинників може бути час відновлення весняної вегетації пшениці озимої (ЧВВВ).
Аналіз основних досліджень і публікацій, у яких започатковано розв'язання проблеми. Час відновлення весняної вегетації $\epsilon$ інтегральним показником наступних умов весняного розвитку зимуючих рослин: світлових (тривалість дня, спектральний склад світла), теплових (інтенсивність сонячної радіації) та водних - у вибутковій частині водного балансу [5]. Цей показник не прогнозує, а визначає, програмує, задає наперед стартові дози зазначених параметрів, тому що змінюється в широких межах (у районі Полтави - від 19 лютого до 17 квітня), що для рослин в обох випадках $\epsilon$ першим днем весняного життя. Ці екстремуми ЧВВВ викликають порушення екологічних зв'язків у системі «рослина патоген - довкілля», що склалися за оптимального ЧВВВ, а ця дія дістала назву екологічний ефект ЧВВВ. На підвалинах теорії екологічного ефекту ЧВВВ створено десятки способів, алгоритмів, технологій, методів селекції рослин в Україні, Росії, Чехії, Німеччині [13], які функціонують у практиці. Вони висвітлені в підручниках із рослинництва [2], генетики і селекції окремих культур [12], програмуванні урожайності [6]. С окремі намагання використати їх в ентомології $[3,7]$. Однак, у фітопатологію ці нові наукові знання допокищо не ввійшли.

Мета і завдання дослідження. 3 метою удосконалення прогнозу появи цієї хвороби та захисту рослин поставлено завдання дослідити вплив ЧВВВ на ураження пшениці озимої бурою листковою іржею.

Матеріали і методика дослідження. Основним матеріалом для опрацювання послужили дані річних наукових звітів Миргородської держсортодільниці за 55 років (1939-1940; 1943-1945; 19472000), що зберігаються в Державному архіві Полтавської області, а також дані спостережень гідрометстанцій та літературні джерела. Матеріал Миргородської сортодільниці відзначається агротехнічною однорідністю (посів по чорному угноєному пару за однакової агротехніки

* Науковий керівник-доктор сільськогосподарських наук, професор В. М. Писаренко 


\section{СТОРІНКА МОЛОДОГО ВЧЕНОГО}

впродовж усіх років), методичною чистотою (оцінка поширення хвороби за шкалою №2 в двох несуміжних повтореннях державного сортовипробування), а також тим, що тут працювали послідовно досвідчені фахівці: фітопатологи за освітою Т. М. Кошевенко, В. Л. Самойлович, кандидат сільськогосподарських наук Н. I. Нечипоренко. Дату відновлення весняної вегетації реєстрували за методикою Держкомісії з випробувань та охорони сортів рослин. 3 усього набору конкурсного (розширеного) сортовипробування ми використали дані по стандартному (тобто, кращому районованому) сорту, який найбільше відповідає вимогам до сортуекотипу. За названий період стандартні сорти змінювали один одного в такій послідовності: Українка 246, Лісостепка 75, Білоцерківська 198, Миронівська 808, Одеська 51, Охтирчанка, Альбатрос одеський - усі вони середньостійкі до ураження хворобами. Дослідження проводили за методами статистичного групування даних із визначенням варіаційного коефіцієнта й агрономічного аналізу [11].

Результати досліджень. Встановлено, що відновлення весняної вегетації пшениці озимої в районі Миргорода відбувалося, в середньому, за 55 років 26 березня, 3 найбільшими відхиленнями від 19 лютого (1995, 2002 рр.) до 17 квітня (1963, 2003 рр.). За цей період було 37 років з ураженням рослин бурою листковою іржею, в т. ч. зі ступенем ураження понад 50 \% 12 років, понад 70 \% листкової поверхні - 3 роки. Найбільший розвиток хвороби відбувався в роки, коли весняна вегетація рослин відновлювалась в оптимальний термін - 2131.03 (табл. 1), що свідчить: патоген добре пристосувався саме до оптимальних умов життя рослинигосподаря. В таблиці 1 звертає на себе увагу відсутність або незначне ураження рослин у роки 3 ранньою вегетацією (від 19.02 до 20.03), що не потребує хімічних засобів захисту. За ці 19 років ли- ше один раз (у 1977, досить вологому році) ураження досягло 53 \% листової поверхні, але воно проявилося пізно - перша генерація не змогла розвинутися, тому мало позначилося на врожайності (53,3 ц/га). Незначний коефіцієнт варіації свідчить про стійкість такої залежності. Навпаки, значне варіювання (дисперсія) даних у роки 3 оптимальним, а також пізнім ЧВВВ свідчить про потужній вплив на розвиток патогена ще якихось факторів. Одним із таких факторів, що піддаються завчасному прогнозуванню, може бути періодичність сонячної активності, яка вимірюється кількістю плям на сонячному диску (числом Вольфа W).

Дійсно, така залежність існує (табл. 2). Вона полягає в тому, що найчастіше і найбільше посіви пшениці озимої на Миргородській сортодільниці уражувалися бурою іржею в роки 3 помірною сонячною активністю (61-120 W) як за оптимального, так (особливо) й за пізнього ЧВВВ. За малої сонячної активності $(1-60 \mathrm{~W})$ уражуваність була меншою, а за високої - зовсім незначною. На перший погляд, здається дивним, що найбільший розвиток збудника бурої іржі збігається не $з$ максимальною, а середньою сонячною активністю. Проте з'ясувалося, що це узгоджується з законами астрофізики. Саме так поводить себе основний показник випромінювальної здатності Сонця - сонячна постійна Ео в залежності від періодичності його активності: вона стрімко зростає в міру збільшення числа сонячних плям 3 1 до 60, досягає максимуму $\mathrm{W}=61-120$, після чого спадає, досягаючи найменших значень при $\mathrm{W}$, рівному 250 [8].

3 аналізу даних таблиць 1-2 бачимо, що незначний розвиток збудника бурої листкової іржі пшениці в умовах Миргорода, який не потребує застосування заходів захисту (якщо цього не вимагають інші хвороби), спостерігається в роки 3 відновленням весняної вегетації рослин раніше

\section{1. Кількість років з ураженням та середній відсоток ураження бурою листковою іржею стандартного сорту пшениці озимої в державному сортовипробуванні за 55 років}

\begin{tabular}{|c|c|c|c|c|c|c|c|}
\hline \multirow{3}{*}{ ЧВВВ } & \multicolumn{4}{|c|}{ Кількість років } & \multicolumn{2}{|c|}{$\begin{array}{l}\text { Середній відсоток ура- } \\
\text { женої листової поверхні }\end{array}$} & \multirow{3}{*}{$\begin{array}{c}\text { Варіацій- } \\
\text { ний кое- } \\
\text { фіцієнт, V } \\
\text { \% }\end{array}$} \\
\hline & \multirow[b]{2}{*}{ разом } & \multicolumn{3}{|c|}{ у тому числі } & \multirow[b]{2}{*}{$\begin{array}{c}\text { за роки } \\
\text { ураження }\end{array}$} & \multirow[b]{2}{*}{ за всі роки } & \\
\hline & & без ураження & $\begin{array}{c}3 \text { ураженістю } \\
>50 \%\end{array}$ & $\begin{array}{c}3 \text { ураженістю } \\
>70 \%\end{array}$ & & & \\
\hline $19-28.02$ & 6 & 3 & & & 19,7 & 9,8 & 7,7 \\
\hline $1-10.03$ & 3 & 3 & & & 0 & 0 & 0 \\
\hline $11-20.03$ & 10 & 3 & 1 & & 24,1 & 16,9 & 6,8 \\
\hline $21-31.03$ & 21 & 6 & 6 & 1 & 45,4 & 31,3 & 29,0 \\
\hline $1-10.04$ & 11 & 3 & 4 & 2 & 37,2 & 31,0 & 11,7 \\
\hline $11-20.04$ & 4 & - & 1 & & 28,7 & 28,7 & 15,6 \\
\hline $\begin{array}{l}\text { Усього } \\
\text { років }\end{array}$ & 55 & 18 & 12 & 3 & & & \\
\hline
\end{tabular}


СТОРІНКА МОЛОДОГО ВЧЕНОГО

\section{2. Вилив сонячної активності $W$ на ураження пшениці озимої бурою листковою іржею в роки з оптимальним і пізнім ЧВВВ}

\begin{tabular}{|c|c|c|c|}
\hline \multirow{2}{*}{ Показник } & \multicolumn{3}{c|}{$\mathrm{W}$} \\
\cline { 2 - 4 } Оптимальний ЧВВВ (21-31.03), 21 рік & $121-190$ \\
\hline Середній \% ураження & 32 & 57 & 14 \\
\hline Число років & 12 & 5 & 4 \\
\hline у т. ч. 3 ураженням понад 50\% & 3 & 3 & 0 \\
\hline Передній ЧВВВ (1-20.04), 15 років \\
\hline Число років & 27 & 81 & 26 \\
\hline у т. ч. з ураженням понад 50\% & 7 & 3 & 5 \\
\hline
\end{tabular}

20 березня - незалежно від періодичності сонячної активності - та в роки з максимальною сонячною активністю ( $\mathrm{W}=120-190)$ незалежно від ЧВВВ. Таких років було 28 із досліджуваних 55, тобто половина. Звичайно, теоретично можливі винятки 3 цього правила - за великих запасів інфекції в природі та за обов'язкової умови постійних дощів, рос, високої вологості повітря у весняно-літній період. Такі умови лише частково спостерігалися один раз за півстоліття в 1980 році. Для практики цей висновок важливий, тому що обгрунтована відмова від обробітку посівів заощаджує кошти, підвищує чистоту продукції, зменшує пестицидне навантаження на довкілля. Проте не менш важливо враховувати тенденцію в зміні часу весняного пробудження озимих рослин. Із тих же даних за 55 років робимо висновок: якщо в 30-х і 40-х роках минулого століття вегетація пшениці озимої відновлювалася в середньому 3-4 квітня, в 50-60-х роках 30-31 березня, то в 90-х роках і в 2001-2010 роках - уже 15-19 березня, в тому числі було 6 років із сталим ЧВВВ у лютому. То ж не випадково останнім часом помітно поменшало бурої іржі у виробничих посівах області. Отже, ЧВВВ постійно «молодшає», збільшується також розмах його відхилень від норми в обидві сторони, що необхідно враховувати в стратегічному прогнозуванні розвитку хвороб.

Залишається дослідити механізм дії ЧВВВ і відповісти на питання: чому такий, здавалося б, малопомітний феномен, як час весняного пробудження рослин, має таку потужну дію в системі агробіоценозу? Рання вегетація - це коротка зима і тривала весна, пізня вегетація - тривала зима і коротка весна. ЧВВВ, по суті, є те ж саме, що висота сонця над горизонтом. Наведені вище найбільші відхилення ЧВВВ від норми 19 лютого і 17 квітня для рослин і збудників хвороб - це не різні дати, а в обох випадках перший день ве- сняного пробудження життя. У першому випадку (19 лютого) сонце досягає лише $28^{\circ}$ висоти в апогеї - сонячний промінь, долаючи товстий шар земної атмосфери, втрачає короткохвильову частину спектру; протягом короткого дня до землі досягають лише оранжево-червоні промені низьких енергій (сумарна радіація 310 кал·см ${ }^{2}$ доба). У другому випадку в перший день пробудження рослин 17 квітня сонце перебуває на висоті $50,3^{\circ}$ в апогеї; за тривалий день воно посилає на землю енергію 615 кал·см ${ }^{2}$ на добу. Це впливає на стартову температуру розвитку рослин і збудників хвороб (табл. 3) незалежно від зміни погоди.

Зараження рослин теліоспорами іржі відбувається за температури від 2,5 до $31{ }^{\circ} \mathrm{C}$ (оптимум $15-25^{\circ} \mathrm{C}$ ) за умов наявності крапель роси чи дощу на листках [9]. Інші автори [10], як мінімальну середньодобову температуру зараження, називають $+5{ }^{\circ} \mathrm{C}$. Наведені в табл. 3 температури сприятливо для патогена складаються за оптимального ЧВВВ і несприятливо - за раннього ЧВВВ в перші дві декади після відростання. Для рослин, навпаки, ці температури за раннього ЧВВВ $\epsilon$ виключно сприятливими для нарощування біомаси, через що вони швидко стають невразливими для патогена, хоч який запас інфекції буде в природі. Саме цим пояснюється незначний розвиток бурої іржі або ії відсутність у роки з раннім ЧВВВ. Як вказує автор теорії екологічного ефекту ЧВВВ В. Мединець [5], у такі роки посіви пшениці озимої в кінцевому підсумку утворюють густоту продуктивних стебел 600-800 шт. на $1 \mathrm{~m}^{2}$, урожай сухої біомаси 150-200 ц/га, а за пізньої вегетації посіви переважно зріджені (250-350 продуктивних стебел на парах), низькорослі, легко продуваються вітром, через що часом утруднюють розвиток бурої іржі в порівнянні з оптимальним ЧВВВ. 
3. Стартова середньодобова температура повітря перших декад після весняного пробудження рослин пшениці озимої в роки з найранішим та найпізнішим ЧВВВ

\begin{tabular}{|c|c|c|c|c|c|}
\hline \multirow{2}{*}{ Показник } & Оптимальний & \multicolumn{2}{|c|}{ Рання вегетація } & \multicolumn{2}{c|}{ Пізня вегетація } \\
\cline { 3 - 6 } & ЧВВВ (норма) & 1998 рік & 2001 рік & 1963 рік & 2000 рік \\
\hline Дата ЧВВВ & 26.03 & 22.02 & 11.03 & 17.04 & 5.04 \\
\hline \multicolumn{2}{|c|}{ Середньодобова температура після весняного пробудження рослин, ${ }^{\circ} \mathrm{C}$} \\
\hline Перших 10 діб & 5,9 & 1,8 & 5,4 & 11,5 & 10,6 \\
\hline Других 10 діб & 8,2 & 3,6 & 1,6 & 15,6 & 15,6 \\
\hline Третіх 10 діб & 10,5 & 7,7 & 8,0 & 19,1 & 14,3 \\
\hline Четвертих 10 діб & 12,6 & 9,5 & 10,3 & 19,9 & 13,2 \\
\hline За 40 діб & 9,9 & 5,7 & 6,3 & 16,6 & 13,4 \\
\hline
\end{tabular}

Висновки: 1. За 55 років державного сортовипробування на Миргородській сортодільниці пшениця озима відновлювала весняну вегетацію, в середньому, 26 березня з відхиленнями в окремі роки від 19 лютого до 17 квітня.

2. Найбільший розвиток бурої листкової іржі на посівах пшениці озимої відбувався за оптимального ЧВВВ (21-31 березня), тому що патоген добре пристосувався саме до оптимальних, зокрема теплових, умов життя рослини-господаря.

3. Найменший розвиток збудника бурої листкової іржі на пшениці озимій (що не вимагає застосування заходів захисту) спостерігався в роки 3 ранньою вегетацією (від 19 лютого до 21 березня) практично незалежно від погоди і сонячної

\section{БІБЛІОГРАФІЯ}

1. Білявський Ю. В. Результати аналізу фітосанітарного стану різних сортів озимої пшениці / Білявський Ю. В., Вусатий Р. О. // Вісник ПДАА, №2. $-2009-$ C. 31 .

2. Зінченко O. I. Рослинництво / Зінченко О. І., Салатенко В. Н., Білоножко М. А. - К. : Аграрна освіта, 2001. - 376с.

3. Исмагилов Р. Р. Фитоценотический подход к оценке вредоносности внутристеблевых фитофагов озимой ржи / Исмагилов Р. Р. // Вестник сельскохозяйственной науки. - №2, 1992. - С. 12.

4. Мединеи В. Д. Весеннее развитее и продуктивность озимых хлебов [Мединец В. Д.]. - М. : Колос, $1982 .-185 \mathrm{c}$.

5. Мединеи В. Д. Интегральный показатель для озимой пшеницы / Мединец В. Д. // Зерно, 2010. №12. - C. 52.

6. Муха В. Д. Програмування врожаїв / Муха В. Д., Пелипець В. Н. - К. : Вища школа, 1988. - 252 с.

7. Писаренко С. В. Закономірності багаторічної динаміки популяцій і прогноз масового розмноження найголовніших шкідників озимої пшениці в Лівобережному Лісостепу України // дис. ... активності та в роки високої сонячної активності $(120-190 \mathrm{~W})$ незалежно від ЧВВВ. Таких років було 28 із досліджуваних 55.

4. Весняна вегетація рослин настає раніше, ніж застосовують заходи захисту, тому висновки, викладені в п. 3, дають можливість запобігти епіфітотій або утриматися від обприскування фунгіцидами, що зменшує витрати, забезпечує чистоту продукції та зменшення пестицидного навантаження на довкілля.

5. Запропоновано для використання в стратегічному, завчасному та оперативному прогнозуваннях розвитку збудника бурої листкової іржі новий показник - час відновлення весняної вегетації пшениці озимої.

канд. с.-Г. н. - Х., 2005.

8. Рвачёв $B$. Введение в биофизическую фотометрию / Рвачёв В. // Львів : из-во Львовского университета, 1966. $-143 \mathrm{c.}$

9. Секун М. П. Основні шкідники і хвороби. Зернові колосові культури. / Секун М. П., Лисенко С. В. // Довідник із захисту рослин. - К. : Урожай, 1998. $98 \mathrm{c.}$

10. Сотникова А. Б. Ржавчинные болезни озимой ржи / Сотникова А. Б. // Защита и карантин растений. - №4, 2012. - С. 54.

11. Федин M. A. Методика государственного сортоиспытания сельскохозяйственных культур [Федин М. А.]. - Вып. 1. - М. : Калининская областная типография, 1985. - 267 с.

12. Чекалін M. М. Селекція та генетика окремих культур: навчальний посібник / Чекалін М. М., Тищенко В. М., Баташова М. Є. - Полтава: ФОП Говоров С. В., 2008. - 368 с.

13. Schulzke Dietrich. Ein neues Algorithmus schlogespesifisches Einsatz von Wachstumsregulatoren in der Winter-getzeidepzo-duktion der DDR // Tagunsber Akd. Landwirtschaftswiss DDR. - №243. - P. 142. 